\title{
Translation and Performance Cultures: Spanish Drama and Restoration England
}

\author{
Jorge Braga Riera
}

\begin{abstract}
From 1660 onwards, Restoration dramatists drew on seventeenth-century Spanish theatre in search of new plots and characters that might appeal to London audiences. Despite the socio-historical differences between two distinct theatrical traditions, practitioners managed to turn the foreign plays into actable English texts.

By comparing a corpus of classical Spanish plays and their versions in Restoration England, this paper aims to provide some insight into the translation strategies employed. In this sense, two performance-oriented mechanisms can be distinguished. On the one hand, many elements in the source texts were naturalised to meet the demands of the target culture, as perceived not only in the treatment of rhythm, versification and rhetorical devices but also in action, act-division and characterisation. This domesticating method is also noticeable in how the central motifs of the comedia, i.e. comicality (stage and linguistic), honour and love, were approached. On the other hand, some aspects in the originals (storylines, names and certain stylistic features) were maintained, manifestly showing the Spanishness of the play-text. A contrastive study leads to significant conclusions on the success of these tailor-made, accommodating formulas, and raises questions about the extent to which the translators reach the status of authors by leaving a visible mark on their creations.
\end{abstract}

\section{Keywords}

theatre translation, drama adaptation, Restoration England, Spanish comedias, naturalisation, visibility

This article was supported by the Czech Science Foundation project GA19-07494S. English Theatre Culture 1660-1737. 


\section{Introduction}

When, in May 1660, Charles II returned to England and restored monarchy following a hiatus of eighteen years, he started an era of contrast that resulted in constant political, religious and social changes. This turmoil also had its effect on drama: theatregoers now demanded plays that satisfied equally the refinement of the courtiers and the lower classes (NICOLL 1978: 106), while confronting Puritan criticism on the basis of "immorality". The outcome was one of the chief periods of dramatic activity in the country as well as a golden time in translation in which Spanish sources played their part. ${ }^{1}$

The eruption of Drama Translation Studies in the 1980s, especially after the publication of Zuber-Skerritt's celebrated compilation (ZUBER-SKERRITT 1984), coincidentally came hand in hand with a renewed interest in Spanish Golden Age theatre in English, both in the UK and the United States, with studies (CASTILLA 2003; RUANO DE LA HAZA 2005; PAUN DE GARCIA and LARSON 2008; BOYLE and JOHNSTON 2008; MUJICA 2013; JOHNSTON 1996, 2015) that concurred on the current unfamiliarity of British and American audiences with Hispanic classics outside academic circles.

Several factors can explain their limited presence in contemporary English translation, among them the plays' "difficult universality" (JOHNSTON 1996: 92), which is perceived in their polymetric structure, Catholic nature, the constant turns and counterturns in the plot with the occasional lengthy soliloquies, or the intricate code of honour and its subsequent pairing of couples (BRAGA RIERA 2013). ${ }^{2}$ Also relevant are present-day editorial practices and the traditional reluctance of Anglo-American publishing houses towards translation in general (the so-called "three per cent problem", as explained by POST 2011). ${ }^{3}$

1 Loftis (1996: 24) affirms that 440 new plays (or transformed old ones) were premiered between 1660 and 1700, with a total of 180 playwrights who wrote them (STYAN 1986: 5).

2 The limited presence of Hispanic classics in English continues even though numbers are increasingly growing, not only with reader-oriented texts but also with translations intended for the stage. Thus, Zatlin admits that "the percentage of translations for theatrical productions in the United Kingdom is considerably higher than the percentage for published books" (ZATLIN 2005: 18). Different initiatives have contributed to this, among others the Channels Project of the Royal National Theatre for the staging of foreign drama, or the commitment of the Gate Theatre to the performance of theatre in translation. In the US, The American Theater Communications Group encourages the publication of theatre translations, whereas the US Theatrical Translation Database and the American Theater Translation Project offer the possibility of incorporating into their databases performed texts without a printed version. For its part, the Association of the Hispanic Classical Theatre aims "to promote and foster greater appreciation for Spain's classical drama in production" (Available online at http://www.comedias.org/about.html).

3 Hale \& Upton (in ZATLIN 2005: 18) cite the US and the UK as the Western countries with the lowest translation rate for books: about $2 \%$ at the turn of the new millennium, which visibly contrasts with figures in Germany (14\%) or Italy (26\%). Venuti (2004: 12-17) confirms these data. Focusing on theatre, Laera (2020: 67 ) points out that " $3.8 \%$ of all plays in the UK in 2013 were translations, and $2.2 \%$ of all performances according to the British Theatre Repertoire 2013)". This rate was probably higher in the 1500s and 1600s: in the second half of the fifteenth century, the number of translations into English accounted for $20 \%$ of all the works published in the country (DELISLE and WOODSWORTH 1995: 201). 
Even accounting for obvious temporal and cultural distances, a parallel trend can be perceived in post-1660 England. Nonetheless, and although described by some scholars as quantitatively "limited" (SEWARD 1972: 102-103), the presence of foreign drama from Spain is hugely significant from a qualitative standpoint, since its study can lead to information about preferred authors, plays and genres, as well as the mechanisms followed by practitioners to make their product succeed (or not) on the stage.

\section{Translation in Restoration England (1660-1710) ${ }^{4}$}

The study of translators in seventeenth-century England must inevitably entail a revision of the prefaces or dedications in which they occasionally reflected on the motivations, pains, shortcomings and virtues of this activity (BENNETT 1989: 67-68; RABADÁN ÁLVAREZ 1987: 253). Even though there does not seem to be an agreement on the guiding principles that should be followed in the process (BENNETT 1989: 73), two fundamental trends are apparent: one based on the supremacy of the original, the other centred on the aesthetics of the target text. Both lines were subject to peer criticism; however, a "libertine" (STEINER 1975: 28) approach prevailed, something that should not come as a surprise since most translators were amateur, had various jobs and were mainly drawn to translation due to their interest in a particular subject. In the specific case of literary works, ${ }^{5}$ a few (non-exclusive) "professionals" can be found (BURKE 2007: 12), who mainly resorted to Latin and Greek poetry and prose, but also to Spanish and French texts (KITIGATI 1981: 2), with French sometimes acting as a bridge for indirect translation from Spanish to English. The profile of these "poets" was far from matching the requisites a good translator should meet, among them the ability to "keep the sense 'sacred and inviolable' and be literal where gracefulness can be maintained" (DRYDEN 1680: 242). ${ }^{6}$

It is to Dryden, a pioneer in reflecting extensively about poetry translation (STEINER 1975: 31), that we owe the first division of translation methods in English. His taxonomy lies on three different pillars or "heads", outlined in his prologue to Ovid's Epistles (1680): metaphrase, "or turning an author word by word, and line by line" (STEINER 1975: 237); paraphrase, "where the author is kept in view by the translator, so as never to be lost, but his words are not so strictly followed as his sense; and that too is admitted to be amplified, but not altered" (STEINER 1975: 237); and imitation, where the translation "(if now he has not lost that name) assumes the liberty, not only to vary from

4 I follow R.D. Hume's temporal division, as internally cohesive from a theatrical perspective (HUME 1976: 10). This period includes four reigns: King Charles II (1660-1685), King James II (1685-1689), William and Mary (1689-1702) and Queen Anne (1702-1714). Loftis (1973: 65) considers the years 1660-1668 as capital in the development of the "Spanish romance" in England.

5 Literature (prose fiction, poetry, drama) was not by far the most popular choice: religious texts were recurrently translated, as well as works related to travel and geography, botany, anatomy, history and art, among others (BURKE 2007: 12).

6 See (STEINER 1975: 28) for the ten requisites, or "talents", formulated by Dryden in this sense. 
the words and sense, but to forsake them both as he sees occasion" (STEINER 1975: 237). Despite his initial preference for the paraphrase - imitation and metaphrase are "two extremes which should be avoided" (STEINER 1975: 241), and "too faithfully is, indeed, pedantically" (STEINER 1975: 237) - later in his career Dryden regarded imitatio as necessary if to assume "that author would have done, had he lived in our age, and in our country" (STEINER 1975: 238), as well as the best way to make himself visible (SLOMAN 1985: 25). Indeed, in his preface to the Sylvae: Or, The Second Part of Poetical Miscellanies, Dryden openly justifies reductions and suppressions in translation practice:

Where I have taken away some of their expressions, and cut them shorter, it may possibly be on this consideration, that what was beautiful in the Greek or Latin, would not appear so shining in the English [...] For, after all, a translator is to make his author appear as charming as possibly he can, provided he maintains his character and makes him not unlike himself [...] Suppose two authors are equally sweet, yet there is a great distinction to be made in sweetness, as in that of sugar and that of honey. (DRYDEN, Sylvae: Or, The Second Part of Poetical Miscellanies, 1685: 252-255)

This "loose" approach is a constant in his work as a translator not only of poetry (the genre to which this classification applies) but also of prose, where verbatim untranslated quotations, paraphrases, glosses, etc. are constant (CURRELL 2006: 162). Despite the fact his reflections do not aim at theatre practice, as a drama translator he also seems to be an "imitator", according to his preface to An Evening's Love, or the Mock Astrologer (1671), originally a play by Calderon de la Barca: "I have rejected some adventures which I judged were not divertising; that I have heightened those which I have chosen; and I have added others which were neither in French nor Spanish" (B3v). This formula is not different from others in contemporary theatre translation typically categorised as "adaptation" or "version", and which obey to the dual nature of the dramatic genre and the weight that context and performative aspects have here, both verbal and extralinguistic (bodily expression, gesture, the playing space, etc.). The following section will concentrate on the selected plays, as well as on the socio-historic factors that facilitated their occurrence in London playhouses.

\section{Plays and context}

On discussing imported plays in translation, Aaltonen (2000: 53) points out that "foreign works are selected based on some discursive structures which either need to be in line with those in the target society or can be made compatible with them". This idea implies that, when resorting to foreign materials, translators select a recognisable culture (and language), but also contents and genres that are well-suited for the recipients. Such circumstance applies to the five English Restoration plays that are distinctively featured as "proper" translations from Spanish (Table 1). Premiered between 1660 and 
$1685,{ }^{7}$ original plots and themes seemed to be familiar enough as "rewritable" material for a particular theatrical society, in accordance with contemporary translation notions: ${ }^{8}$

Table 1: Translations from Spanish plays during the Restoration.

\begin{tabular}{|c|c|}
\hline ENGLISH PLAY & TRANSLATED FROM \\
\hline $\begin{array}{c}\text { The Adventures of Five Hours } \\
\text { (Samuel Tuke, 1663) }\end{array}$ & $\begin{array}{l}\text { Los empeños de seis horas } \\
\text { (Antonio Coello, 1657) }\end{array}$ \\
\hline $\begin{array}{c}\text { Elvira, or the Worst Not Always True } \\
\text { (George Digby, 1664). }\end{array}$ & $\begin{array}{l}\text { No siempre lo peor es cierto } \\
\text { (Calderón de la Barca, 1648-1650) }\end{array}$ \\
\hline $\begin{array}{l}\text { Tarugo's Wiles; or: the Coffee-house } \\
\text { (Sydserf, 1667) }\end{array}$ & $\begin{array}{c}\text { No puede ser el guardar una mujer } \\
\text { (Antonio Moreto, 1659) }\end{array}$ \\
\hline $\begin{array}{c}\text { An Evening's Love, or the Mock Astrologer } \\
\text { (John Dryden, 1668) }\end{array}$ & $\begin{array}{c}\text { El astrólogo fingido } \\
\text { (Calderón de la Barca, 1641) }\end{array}$ \\
\hline $\begin{array}{l}\text { Sir Courtly Nice, or It Cannot Be } \\
\text { (John Crowne, 1685) }\end{array}$ & $\begin{array}{c}\text { No puede ser el guardar una mujer } \\
\text { (Antonio Moreto, 1659) }\end{array}$ \\
\hline
\end{tabular}

A close look at Table 1 reveals a striking absence: Calderon de la Barca's Life's a Dream (1635), which has been recurrently retranslated in the twentieth and twenty-first centuries (THACKER 2007: 16). ${ }^{9}$ The remaining authors, Antonio Moreto and, especially, Antonio Coello, are ranked below other more celebrated playwrights such as Lope de Vega and Tirso de Molina. ${ }^{10}$ There is evidence that two other Calderonian plays found

7 The corpus selection relies on the studies by SEWARD (1972), LOFTIS (1973, 1996), HUME (1976), HOGAN (1995) and BRAGA RIERA (2009), all of whom (in whole or in part) centred their attention on the presence of Spanish drama in seventeenth-century Britain. There is no coincidence, though, in the categorization of the resulting plays. Loftis (1973: 95) describes them as "essentially translations", but uses concepts as "adaptation" and "version" with little rigour; hence, The Adventures and Elvira are, in his view, "free adaptations" (LOFTIS 1973: 80), while the former is also seen as a translation and an adaptation (ibid.: 71). He, too, defines Sir Courtly as a "loose translation" in some parts (LOFTIS 1973: 88) but "freer" (ibid.: 159) than that of Sydserf's, which seems to have "paraphrased" the Spanish source (LOFTIS 1973: 90). For her part, Hogan (1995) adopts the word "adaptation" to describe all cases, although at times she timidly uses the expressions "plays based on", "plays that show inspiration of"; or even "free translation" (HOGAN 1995: 123) when referring to The Adventures.

8 Plays originating in non-dramatic Spanish sources are not considered in this analysis, as might be the case of Dryden's The Rival Ladies (1664), apparently based on Cervantes's novella Las dos doncellas (which also inspired Fletcher's Love's Pilgrimage, c1615), or Roger Boyle's Guzman (1669) and Thomas Duffett's The Spanish Rogue (1673), both probably deriving from the picaresque novel Guzmán de Alfarache (LOFTIS 1973: 162).

9 Although partially following the plot, Aphra Behn's The Young King (1679) cannot be strictly considered a translation of Calderon's masterpiece. Behn might have read the original or used French or English intermediaries for inspiration, as did Wycherley with The Gentleman Dancing-Master (from El maestro de danzar), or Love in a Wood, which echoes Mañanas de abril y mayo (LOFTIS 1973: 121-122; RODRÍGUEZ LORO 2016).

10 The first of Lope's plays to ever be translated into English was Don Lope de Cardona, which James Shirley turned into The Young Admiral (1633). There is no record of any other translation of a Lopean play until 1934, when The Gardener's Dog was published in New York (BRAGA RIERA 2019b: 223). 
their way to the London stage in 1664: 'Tis Better than It Was and Worse and Worse, from Mejor está que estaba and Peor está que estaba, respectively (LOFTIS 1973: 45). Since they are lost no comparative analysis can be carried out, and hence they will be omitted from this study.

\section{Patronage and translators}

When Charles II recovered the throne, he brought his dramatic taste with him. During his exile in France and the Netherlands (where Spanish was spoken at court), the king had become acquainted with not only Spanish theatre but also French plays (which were strongly influenced by everything Hispanic). It is difficult to venture on the number of Spanish plays he read or saw performed, in the original language, in French, or even in Dutch, but it is a fact that he recommended Spanish works to Samuel Tuke and John Crowne once in England (HUME 1973: 339). It is not coincidental, either, that Sydserf and Digby had accompanied the monarch in the Low Countries. Consequently, the translators used prologues and epilogues to thank him or other prominent figures so as to obtain their favour: both Tuke and Crowne acknowledged the promoter of their texts and dedicated them to the Queen, while Dryden and Sydserf made praising dedications to two members of the nobility. ${ }^{11}$

Except for the theorist John Dryden, these men were inexperienced and without interest in literary projects. Tuke was a colonel and Digby an English grandee part of the royal circle; Sydserf, apparently a Royalist knight, also served on the continent, whereas Crowne pursued a career in public office. Apart from Madrid-born Digby, their language proficiency is unknown: they probably gained knowledge of Spanish and its drama when in exile, and might have resorted to dictionaries, manuals, grammars and books written in that language, which were then available in London (LOFTIS 1973: 59; HOGAN 2005: 49-52). The result is a product whose quality is affected both in content and form if compared to its source, but still deserves credit as responsible for the "establishment of the Restoration Spanish plot" (LOFTIS 1973: 67) in England, which in turn led to the advent of many other Spanish Golden Age-inspired plays.

\section{The genre}

The fact that none of the source texts selected were farces or tragedies (despite Tuke's inaccurate description of his play as "tragicomedy") fits with the idea of entertainment as the chief end of Restoration drama "with instruction only remotely second" (WILSON 1965: 121). Dryden himself confirmed his preference for comedies where "gayety" and "making love" were central (CORMAN 2000: 97), in the mood of Fletcher's comedy of

11 The motivation to please the King is also present in the dialogues, and might be the reason why allusions to the Spanish monarchy in the source texts were omitted, i.e. the line when Don Diego announces in El astrólogo fingido that he was born "in the Court of Phillip" (p. 239). 
wit. ${ }^{12}$ The Interregnum in which theatres were closed limited the number of available new plays, so it was necessary to find other materials apart from earlier comic authors (in many cases rewritten to please the new audiences): French playwrights (mainly - but not exclusively - Molière, who in turn had been influenced by Spanish theatre $)^{13}$ and Spanish sources (the so-called "comedy of intrigue", ${ }^{14}$ filled with nocturnal conspiracies, encounters, duels, confusion of identities, etc.), both "a fertile field for pillaging" (CORMAN: 2000: 98).

\section{Translating the Comedia ${ }^{15}$}

A crucial decision in the process of translating theatre is whether to reduce the foreign text to the cultural values of the target language or mark the cultural difference of the foreign text, choices branded by Venuti as "domesticating method" and "foreignising method", respectively (VENUTI 2004: 20)..$^{16}$

By looking into the translation method followed in the plays in the corpus, the following paragraphs intend to critically examine their degree of adaptation to the target culture. To this aim, we shall consider aspects such as plots, play structure and titles, as well as the treatment of names and culture-related items, and how honour, love and humour are integrated into the resulting texts. In all cases, the emphasis is placed on the extent to which the "foreign" presence is toned down or unintegrated, or if, on the contrary, it is naturalised following social and performance conventions, hence (partially) minimising the Spanishness of the source plays.

\section{Titles, plots and structure}

The five translations studied here follow the plays' plots, but with alterations such as scene relocations and divisions, omissions and, at times, straight deletions. Additions are relevant too, with changes that affect characterisation (for instance, Digby and Dryden make their gracioso, the comedia's comic figure, more outspoken) or provoke

12 Fletcher andJonson were most popular once the theatres reopened in 1660, with "Shakespeare's comedies placed in a distant third" (CORMAN 2000: 98; see also BICKLEY and STEVENS 2020). Roberts (2014: 15) also highlights the presence of heroic drama during the Carolean period, with translations of French texts by Racine and Corneille. See (ROBERTS 2013) for further detail.

13 There is solid evidence of the effect that some French translations of Spanish classics had in English authors. Davenant used a French text of Donde hay agravios no hay celos for his The Man's the Master, and so did Shadwell with The Libertine and John Corye's with The Generous Enemies, to mention a few (LOFTIS 1973; HOGAN 1995).

14 Throughout the literature, these plays are also referred to as "Spanish intrigue comedies", "Spanish plots", "imitations of the comedia", etc.

15 This Spanish term does to encompass "comedy" as a genre exclusively, but any Spanish regular-verse drama.

16 Aaltonen (2000: 55) describes the former as "acculturation" or "naturalisation". 
alterations on textual and stage levels. These alterations may respond to an intent to indulge the public (the servants' love affairs in The Adventures, or Dryden's happy ending in An Evening's Love recreating four marriages against one in the original), reinforce humoristic passages (the scene in The Adventures where the Dutch are mocked), or impress the auditorium utilizing state-of-the-art stagecraft (Tuke makes a woman light a candle with her breath). Other insertions are musical (i.e. Elvira singing a song surrounded by Valencian orange trees and fountains), ${ }^{17}$ if not topical or situational: hence the complete new scene (III) in Tarugo's Wiles, where typical English patrons discuss current events in a coffee-house (a place that recalls the literary salon described by Moreto in No siempre, but missing in Sydserf's text), or Crowne's incorporation of three new characters (Surly, Aunt and Sir Courtly) whose spirit is closer to the English comedy of manners.

Many of the adjustments in plot and character had an immediate consequence in title choice. Some double titles reveal a preference for characterisation over action, as seen in Elvira, or the Worst Not Always True; Sir Courtly Nice, or it Cannot Be (with fop Sir Courtly in the spotlight), or Tarugo's Wiles; or: the Coffee House (with clown Tarugo converted into an impoverished Englishman). In the same fashion, Dryden prioritised the courting scenes in An Evening's Love; or the Mock Astrologer to the story of the magician.

Other modifications derive from shifts in dramatic structure: by turning the original three-act division into a five-act play, the six hours of Coello's story (two per act) became five in The Adventures of Five Hours, with the consequent rearrangement of contents.

It is true that the disruption of the Aristotelian unity of action (proposed in 1609 by Lope de Vega in his New Art of Writing Plays) is closely followed for plots and subplots, and that the lack of observance for the unities of time and place in the originals facilitated the task of translators. Nevertheless, the natural flow of the scenes is affected, in part due to decisions related to soliloquies and polymetry. On the one hand, prolonged monologues disappear (the lengthy love declarations uttered by Don Juan and Doña Maria in El astrólogo - 119 lines and 74 lines, respectively - are substituted by a dialogue between the protagonists) or are broken up with character interventions. This disruption can be seen in the following excerpt, where César's words find the constant interruption of his friend Octavio:

17 Song and music are staples in the translated plays, as was customary in Restoration theatre as a whole. Thus, actors and actresses were expected to be able to sing (STYAN 1986: 35). 


\footnotetext{
CES: ...que envuelto en polvo, procura huir del fuego: yo entonces por la puerta, y confuso con el humo, entro en la cuadra, con no sé qué furia oculta, piso horrores, iqué osadía! venzo el riesgo iqué ventura!

Y en la cuadra ;qué dolor!

Miro postrado ;qué angustia!

Entre las llamas iqué pena!

De esta suerte una hermosura.

Los empeños, Jornada I, p. 112
}

\author{
OCT: O how unsafe it is to be secure! \\ ANT: Finding no more Resistance, I made haste \\ to a lofty structure, which, as I conceived, \\ was the likeliest Quarter for their Officer. \\ Led thither by Desire to rescue both, \\ Him, from the Soldiers' rage; That, from the Fire. \\ OCT: A care most worthy of a Gallant Leader. \\ ANT: But think, Octavio, how I was surprised, \\ when, entering the Pavillion i'the Garden, \\ I found a Woman of a Matchless form, \\ stretched all along upon a Marble Floor. \\ The Adventures, Act II, p. 73
}

On the other hand, Dryden's consideration of rhyme in theatre as "unnatural" (DRYDEN 1668) was also shared by his English contemporaries: Crowne and Sydserf opted for prose, only resorting to rhyming couplets at the end of the acts, as some sort of reflection:

Let us retire, Camilla. A little rest

And Meditation, may new aids suggest.

The Adventures, end of Act I, p. 66

Tuke and Digby did not render the rich original metrics either, and chose blank verse with the occasional rhyming couplet. Tuke overused these, but he curiously inserted them in those parts that lacked direct correspondence with the source, facilitating the translator's creativity. Omitting versification logically resulted in texts stripped of the figures of speech, rhetorical devices and phonemic features characteristic to Spanish dramatic poetry.

Last, noticeable differences can be perceived in the treatment of stage directions, too. These are scarce in the original texts and contain little information, mostly indications about action marks or about dress or manners of speaking. English stage directions are usually rich in comparison, and new ones were also added:

Beatriz leyendo un papel, y, tras ella, Inés

[Beatriz reading a note, and behind her, Inés]

No siempre, p. 84

No siempre
Donna Blanca at one door, reading a paper with great marks of passion and disturbance; and her waiting-woman Francisca at another, observing her Elvira, p. 450

Don Zancho and Chichon come out from behind the hanging, and follow her as leading to the balcony. And soon after Don Zancho and Chichon appear as in the balcony, and Francisca's head as peeping out of the door into it.

Elvira, p. 456 
In this second example, Digby saw the humoristic possibilities of a scene in a balcony used by Don Zancho and Chichon to escape, and provided directions on how it should be performed or visualised. This extra detail often made indications inserted in lines unnecessary, with their consequent omission, as perceived in the following case:

\section{OCTAVIO: Los brazos, César, me dad. They embrace.}

[Hug me, César]

Los empeños, p. 111

The Adventures, p. 139

The disappearance of verbal allusions also contributed to the vitality of dialogues. Similarly, many original lines alluding to décor were now unnecessary thanks to the technical facilities of the host theatre. As for indications referring to costume, omissions were sometimes justified by the preference for typical English garments, some of which were not part of the Spanish tradition, such as visor masks.

\section{Names and culture-specific items}

Whilst translators usually respected the prototypical Spanish Golden Age types (ladies, gallants, fathers, and servants), their names underwent profound transformations once in England. Three tendencies are noticeable in this respect: the original names were retained, they were replaced by others equally Spanish, or English ones were used instead. Preservation is evident in Tuke, while Digby and Sydserf opted for different names (though still Spanish). Dryden combined Spanish and, most distinctively, English speaking names, using the latter not only for low-rank characters (Maskall, as customary in comedias) but also for the beaux, as anthroponyms such as Wildblood or Bellamy prove (see Table 2 below):

Table 2: Character names in El astrólogo and An Evening's Love.

\begin{tabular}{|l|l|}
\hline El astrólogo fingido & An Evening's Love; or, the Mock Astrologer \\
\hline DRAMATIS PERSONAE & DRAMATIS PERSONAE \\
\hline HIGH RANK & HIGH RANK \\
\hline Don Juan de Medrano & Don Melchior de Guzman \\
\hline Don Antonio & Wildblood \\
\hline Don Diego de Luna & Don López de Gamboa \\
\hline$\varnothing$ & Bellamy \\
\hline Don Carlos & Don Pedro de Mendoza \\
\hline Leonardo, Viejo & Don Alonzo de Ribera \\
\hline Doña María & Donna Theodosia \\
\hline$\varnothing$ & Donna Jacintha \\
\hline Doña Violante & Donna Aurelia \\
\hline
\end{tabular}




\begin{tabular}{|c|c|}
\hline El astrólogo fingido & An Evening's Love; or, the Mock Astrologer \\
\hline LOW RANK & LOW RANK \\
\hline Morón & Maskall \\
\hline Otáñez, escudero & $\varnothing$ \\
\hline$\varnothing$ & Pedro \\
\hline Beatriz & Beatrix \\
\hline Quiteria & Camilla \\
\hline$\varnothing$ & Musicians \\
\hline$\varnothing$ & Servants to Don Lopez and Don Alonzo \\
\hline
\end{tabular}

$\varnothing$ Without equivalent

This fondness for evocative solutions is also manifest in Crowne, who anglicised most character names, a logical decision since Sir Courtly Nice transports the action to London. The same coherence can be perceived in the Spanish setting Dryden picked for his play (Madrid), and Sydserf's coffee-house scene (set in England).

Foreign locations (Seville, Valencia, Madrid) also entailed transformations of place names, but not of lexical items typical of the foreign culture. Just by focusing on how the Spanish items of clothing were rendered into English, some conclusions can be drawn regarding the translators' general treatment of culture-specific items (see Table 3):

Table 3: The translation of culture-specific items: clothes.

\begin{tabular}{|c|c|c|c|c|c|c|}
\hline Play & LEXICAL TERM & $\begin{array}{c}\text { The } \\
\text { Adventures }\end{array}$ & Elvira & $\begin{array}{c}\text { An Evening's } \\
\text { Love }\end{array}$ & $\begin{array}{l}\text { Tarugo's } \\
\text { Wiles }\end{array}$ & $\begin{array}{l}\text { Sir Courtly } \\
\text { Nice }\end{array}$ \\
\hline All & manto & veil [veil'd] & veil [veil'd] & vail & [veil'd] & $\begin{array}{c}\text { vizard } \\
\text { [vizarded] }\end{array}$ \\
\hline All & (traje de) camino & riding clothes & $\begin{array}{l}\text { riding-cloaths, } \\
\text { habits }\end{array}$ & $\varnothing$ & $\varnothing$ & $\varnothing$ \\
\hline $\begin{array}{l}\mathrm{E}_{1} \mathrm{~A}_{1} \\
\mathrm{~N}\end{array}$ & chapín & $\varnothing$ & - & $\varnothing$ & $\varnothing$ & $\varnothing$ \\
\hline $\mathrm{A}, \mathrm{Np}$ & botas y espuelas & - & - & $\varnothing$ & $\varnothing$ & $\varnothing$ \\
\hline$A$ & (traje) de noche & - & - & $\varnothing$ & - & - \\
\hline $\mathrm{Np}$ & $\begin{array}{l}\text { hábito de San- } \\
\text { tiago }\end{array}$ & - & - & - & $\begin{array}{l}\text { habit of } \\
\text { a Knight }\end{array}$ & $\begin{array}{c}\text { ridiculously } \\
\text { dressed }\end{array}$ \\
\hline $\mathrm{Np}$ & (traje) de criado & - & - & - & $\varnothing$ & $\varnothing$ \\
\hline A & papahígo & - & - & $\varnothing$ & - & - \\
\hline A & capa & cloak & cloak & $\varnothing$ & - & - \\
\hline
\end{tabular}

E: Los empeños de seis horas / A: El astrólogo fingido / N: No siempre lo peor es cierto;

Np: No puede ser el guardar una mujer / - Non-existent in the source play / $\varnothing$ Omissions 
Table 3 reveals few instances of conservation ("veil", "cloak"), whereas omission stands out with some striking examples (see An Evening's Love). The traje de camino ("outdoor wear") is naturalised, and there are ideologically significant implications in other choices (the pilgrimage-related hábito de Santiago is rendered as "ridiculously dressed"). Omissions are sometimes justified: extralinguistic factors could have been enough to provide contextual information, and some items were not familiar to the public at the time (for example chapines or chopines, a sort of cork-made clog). By way of compensation, new items of clothing (such as handkerchiefs, gowns, gorgets, petticoats, aprons, cravats, etc.) proliferated in the translated works.

This tendency to naturalisation is also visible in other semantic fields as those related to dwelling (for instance, the typical Spanish rejas - barred windows for courtship disappeared or were substituted by balconies), and linguistically in the use of proverbs, popular sayings, and pejorative expressions, mostly creations: thus, a word indicating soft aggression, such as villano (a country bumpkin), might turn into an insult in English ("cursed villain" in The Adventures, p. 98). On top of that, when the source lacked in terms of abuse new ones were created, in some cases daringly: "Thou art an ass" (Elvira, p. 451), "A pox on you" (An Evening's Love, p. 321), or extreme "Son of Whore" (Sir Courtly Nice, p. 33). With these expressions, the translators also contributed to the humoristic tone of some scenes.

\section{The motifs of the comedia: honour, love, humour}

Honour and love appear as crucial elements in the development of the plot, since this is always subjected to the imperative that a father (or brother) should see his honour restored after a daughter's (or sister's) inappropriate behaviour (clandestine correspondence with a man, secret encounters, love at first sight, or love declarations from an unsuitable suitor ). This idea of honour linked to "chastity", whose driving force is superior to love, was completely understandable by English audiences, accustomed as they were to duels and honour-related situations in Renaissance English or French plays. Thus, the translators unsurprisingly reproduced these conditions and kept marriage as the solution to restore the offence. Their presence, however, seemed to be excessive for Dryden, who complained about the abuse of honour-related situations in plays, using Wildblood as his spokesman: "Sir [addressing Melchior], I hate your Spanish Honour since it spoil'd our English Plays" (An Evening's Love, Act V, p. 370). Consequently, he gave less prominence to the subplot of Doña María.

Despite the general respect for honour, two differences can be felt in the target versions: first, the reactions of the English ladies to its strict code were bolder, above all in lines added by the translators. In An Evening's Love, Theodosia and Jacintha not only provocatively move aside their cloaks to reveal their faces to their suitors, but they also speak to them more openly than their Spanish counterparts. Secondly, the resulting marriages were servants' object of mockery, mainly - again - in lines without a corre- 
spondence in Spanish. Hence, Diego referred to matrimony as "the worst of all disasters" (The Adventures, p. 127) and Crack scoffed at the idea of long marriages:

As for laughing, I believe you will have an Annuity for Life; but For Love, you'll only have a Lease for three or four Years.

(Sir Courtly Nice, Act III, p. 44)

Regarding humour, the translators do not distance themselves from the laugh-provoking situations of the sources, including stage comicality: gesture, costume, makeup, hairstyle, props, the rupture of the stage illusion and figures of ridicule (fops and drolls), exploiting their multiple possibilities and including their own. Insertions are particularly noticeable in text-based humour (neologisms, witty ripostes, double meanings), where creativity shines. A study of malapropisms and ingenious wordplay in the rendering process reveals few instances of substitution (with results depending on the skill of the translator) and many omissions (mainly when faced with phonetic or strongly culture-based puns), compensated at times - predictably - with new creations that took advantage of the phonological resources of the English language:

D. ZANCHO: Were not born with cauls upon our heads, think'st thou, Chichon, to come off twice a row thus rarely, from such dangerous adventures?

CHICHON: Rather I think with combs, so oft to venture.

(Elvira, p. 472)

Focusing exclusively on the puns in the corpus, and considering global figures of instances of wordplay, the number of additions is extraordinarily remarkable. This is seen in Graph 1 (below), which shows the count of occurrences in the whole corpus under three translating mechanisms: substitution (9\%), omission (32\%) and autonomous creation $(59 \%)$.

Graph 1: Translation strategies and wordplay (from BRAGA RIERA 2019a: 155).

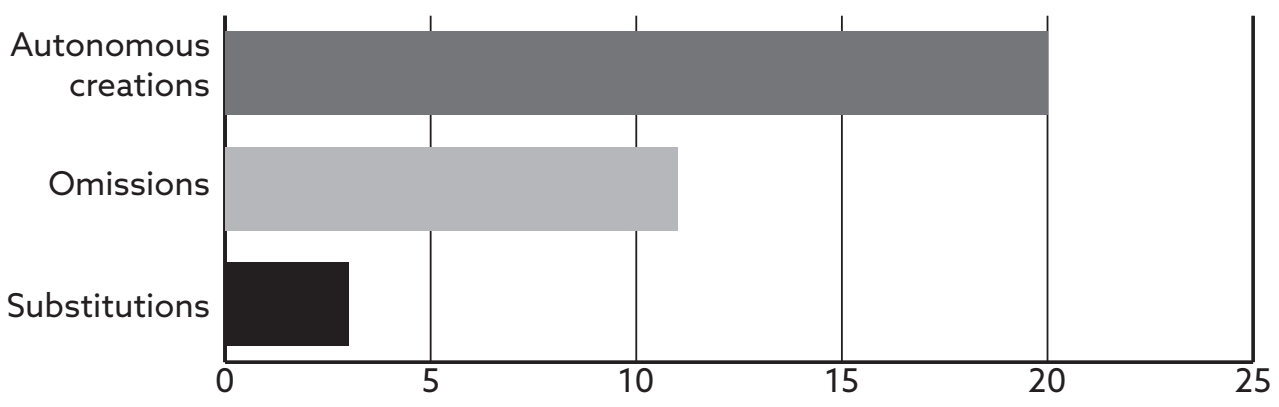




\section{Concluding Remarks}

The particular notion of drama translation in Restoration England implied the selection of foreign texts that could work back home and whose authorship was not as pertinent as genre or royal taste. Despite their inexperience (excluding Dryden), the translators made themselves visible not only in prefaces, dedications and even covers of printed editions but also in the plays themselves, pushing Spanish playwrights and works (in point of fact, not well-known in England) into the background.

In their renderings into English, Venuti's two opposing mechanisms can be observed: foreignisation and domestication. By means of the former, the original nature of the texts was retained, as can be perceived in the partial selection of Spanish names and locations, or the maintenance of love and honour as plot-driving forces. But many other aspects were fully naturalised: skilful versification disappeared, and dialogue substituted many soliloquies, while richer stage directions helped to make exchanges more agile. English proper nouns were used, and clothes, props, proverbs or insults were also accommodated. Honour was downplayed, women were more daring in their attitudes, and a good deal of stage and textual humour was left out, although reinforced with inside jokes and invented wordplay. All told, these distortions were not radically different from others present in translated French texts, or even English plays from the past now transformed for the sake of entertainment. ${ }^{18}$

The target texts became, using Dryden's words, "plots weaved in English looms" with characters and situations reflecting "the Other", but essentially English in nature (WILSON 1965: 126). Despite their comparatively poorer literary value the resulting English texts made their way into the British dramatic repertoire, even serving as inspiration for future Restoration playwrights. ${ }^{19}$ What is more, they succeeded as commercial shows in which the spectacular side was capital (PORTILLO 2005: 63) ${ }^{20}$, meeting the demands of the audience.

18 For instance, using music in dramas such as Hamlet, making The Tempest burlesque or providing happy endings for King Lear or Romeo and Juliet (PORTILLO 2005: 67).

19 There are traces of Digby's translations in Aphra Behn's The Dutch Lover (1673) and The Rover (1677), as well as in Durfey's The Banditti (1686). Tarugo's Wiles also seems to have influenced Davenant's The Man's the Master.

20 This was especially true in the case of The Adventures, with thirteen consecutive performances and a full house according to (PEPYS 1997: 190). 


\section{Bibliography}

\section{Play editions}

CALDERÓN DE LA BARCA, Pedro. 1761. El astrólogo fingido. In Comedias del célebre poeta español Don Pedro Calderón de la Barca, 6. Madrid: Juan Fernández de Apontes, 1761: 225-266.

CALDERÓN DE LA BARCA, Pedro. 1997. No siempre lo peor es cierto. In L. G. Villaverde and L. Fariñas (eds.). Barcelona: Borrás Ediciones, 1997.

COELLO, Antonio. 1657. Los empeños de seis horas. In Andrés García de la Iglesia (ed.). Comedias nuevas escogidas de los mejores ingenios de España, 8. Madrid, 1657: 105-136.

CROWNE, John. 1735. Sir Courtly Nice, or It Cannot Be. London: W. Feales, 1735.

DIGBY, George. 1810. Elvira; or the Worst Not Always True. In The British Ancient Drama, 3. London, 1810: 446-477.

DRYDEN, John. 1760. An Evening's Love, or The Mock Astrologer. In S. Derrick (ed.). The Dramatick Works of John Dryden, 2. London: J \& R Tonson, 1760: 266-383.

MORETO, Agustín. 1950. No puede ser el guardar una mujer. In Luis Fernández Guerra, and Luis Orbe (eds.). Comedias escogidas de D. Agustín Moreto y Cabaña. Madrid: Atlas, 1950: 187206.

SYDSERF, Thomas. 1668. Tarugo's Wiles, or the Coffee-House. London: Henry Herringman, 1668. TUKE, Samuel. 2003. The Adventures of Five Hours. In P. M. S. Hopkins (ed.). London: Ituri, 2003.

\section{General}

AALTONEN, Sirkku. 2000. Time-Sharing on Stage. Drama Translation in Theatre and Society. Clevedon: Multilingual Matters, 2000.

BICKLEY, Pamela and Jenny STEVENS. 2020. Studying Shakespeare Adaptation: From Restoration Theatre to Youtube. London/New York: The Arden Shakespeare, 2020.

BOYLE, Catherine and David JOHNSTON (ed.). 2008. The Spanish Golden Age in English: Perspectives on Performance. London: Oberon Books, 2008.

BRAGA RIERA, Jorge. 2009. Classical Spanish Drama in Restoration English (1660 -1700). Amsterdam/Philadelphia: John Benjamins, 2009.

BRAGA RIERA, Jorge. 2013. The Spanish Classics under Scrutiny: Translating Honour for Modern English-speaking Audiences. The European English Messenger 22 (2013): 2: 36-41.

BRAGA RIERA, Jorge. 2019a. Textual comicality and creativity in drama translation (SpanishEnglish): A diachronic approach. In Frédérique Brisset, Audrey Coussy, Ronald Jenn, and Julie Loison-Charles (eds.). Traduire le jeu de mots. Paris: Presses Universitaires du Septentrion, 2019: 147-167.

BRAGA RIERA, Jorge. 2019b. 'Who killed the Commander?’ La suerte de Fuente Ovejuna en el ámbito inglés ['Who killed the Commander?' The Fortunes of Fuente Ovejuna in the English world]. In J. Huerta Calvo (ed.). Fuente Ovejuna (1619-2019). Perviviencia de un mito universal [Fuente Ovejuna (1619-2019). The Survival of a Universal Myth]. New York: Idea/Igas, 2019: 221-242.

BURKE, Peter. 2007. Cultures of translation in early modern Europe. In Peter Burke, and Ronnie Po-chia Hsia (eds.). Cultural translation in Early Modern Europe. Cambridge: Cambridge University Press, 2007: 7-38. 
CASTILLA, Alberto. 2003. Noticia del teatro del Siglo de Oro en Estados Unidos [News of Golden Age Drama in the United States]. In O. Navarro, and A. Serrano (eds.). En torno al teatro del Siglo de Oro [About Golden Age Drama]. Almería: Instituto de Estudios Almerienses, 2003: 195-201.

CORMAN, Brian. 2000. Comedy. In D. Payne Fisk (ed.). The Cambridge Companion to English Restoration Theatre. Cambridge: Cambridge University Press, 2000: 52-69.

CURRELL, David. 2016. "As He Refined the Language". Dryden's Task as a Translator. Literature Compass 3 (2016): 2: 159-171.

DELISLE, Jean and Judith WOODSWORTH (eds.). 1995. Translators through History. Amsterdam: John Benjamins, 1995.

DRYDEN, John. 1680. An Essay on Dramatick Poesie. In W. P. Ker (ed.). Essays of John Dryden. Oxford: Clarendon Press, 1926: 21-108.

DRYDEN, John. 1680. Preface to the Translation of Ovid's Epistles. In W. P. Ker (ed.). Essays of John Dryden. Oxford: Clarendon Press, 1926: 230-243.

DRYDEN, John. 1685. Preface to Sylvae: Or, The Second Part of Poetical Miscellanies. In W. P. Ker (ed.). Essays of John Dryden. Oxford: Clarendon Press, 1926: 251-269.

HOGAN, Floriana Tarantino. 1995. The Spanish Comedia and the English Comedy of Intrigue with Special Reference to Aphra Behn. [s.l.] [s.n.], 1995.

HUME, Robert D. 1976. The Development of English: Drama in the Late Seventeenth Century. Oxford: Clarendon Press, 1971.

JOHNSTON, David. 1996. Las terribles aduanas: fortuna de Lope de Vega, Calderón de la Barca y Tirso de Molina en inglés [Terrible customs: the fortune of Lope de Vega, Calderón de la Barca and Tirso de Molina in English]. In A. L. Pujante, and K. Gregor (eds.). Teatro clásico en traducción: texto, representación, recepción [Classical Theatre in Translation: Text, Performance, Reception]. Murcia: Universidad, 1996: 89-98.

JOHNSTON, David. 2015. Translating the Theatre of the Spanish Golden Age. London: Oberon Books, 2015.

KITAGAKI, M. 1981. Principles and Problems of Translation in Seventeenth-century England. Tokyo: Yamaguchi Shoten, 1981

LAERA, Margherita. 2020. Theatre E゚ Translation. London: Palgrave Macmillan, 2020.

LOFTIS, John. 1973. The Spanish Plays of Neoclassical England. New Haven/London: Yale University Press, 1973.

LOFTIS, John. 1996. The social and literary context. In T. W. Craik (ed.). The Revels History of Drama in English 1660-1750. Vol. V. London: Methuen, 1996: 3-80.

MUJICA, Barbara (ed.). 2013. Shakespeare and the Spanish "Comedia". Translation, Interpretation, Performance. Essays in Honor of Susan L. Fischer. Lewisburg: Bucknell University Presses, 2013.

NICOLL, Allardyce. 1978. British Drama. London: Harrap \& Co, 1978.

PAUN DE GARCIA, Susan \& Donald R. LARSON (eds.) 2008. The Comedia in English: Translation and Performance. Woodbridge: Tamesis, 2008.

PEPYS, Samuel. 1997. The Concise Pepys. Hertfordshire: Wordsworth Editions, 1997.

PORTILLO, Rafael. 2005. Staging Restoration dramas: practical aspects of their performance. Sederi 15 (2005): 63-80.

POST, Chad W. 2011. The Three Percent Problem: Rants and Responses on Publishing, Translation, and the Future of Reading. www.rochester.edu/threepercent, 2011.

RABADÁN ÁLVAREZ, Rosa. 1987. Apuntes de la teoría de la traducción en la Inglaterra del siglo XVII [Notes for translation theory in seventeenth-century England]. In J. C. Santoyo 
(ed.). Fidus interpres: Actas de las Primeras Jornadas Nacionales de Historia de la Traducción [Fidus interpres: Proceedings of the First National Conference on Translation History]. Valladolid: Servicio de Publicaciones, 1987: 249-254.

ROBERTS, David. 2013. 'Ranked Among the Best'. Translation and Cultural Agency in Restoration Translations of French Drama. The Modern Language Review 108 (2013): 2: 296-415.

ROBERTS, David. 2014. Restoration Plays and Players. An Introduction. Cambridge: Cambridge University Press, 2014.

RODRÍGUEZ LORO, Nora. 2016. De Calderón a Wycherley: adaptación de personajes en The Gentleman Dancing-Master [From Calderon to Wycherley: character adaptation in The Gentleman Dancing-Master]. JACLR: Journal of Artistic Creation and Literary Research 4 (2016): 1: 89-99.

RUANO DE LA HAZA, José María. 2005. Spanish Classical Theory in Britain and North America. Romance Quarterly 52 (2005): 1: 2-12.

SEWARD, Patricia M. 1972. Was the English Restoration Theatre Significantly Influenced by Spanish Drama? Revue de Littérature Comparée 46 (1972): 95-125.

SLOMAN, Judith. 1985. Dryden: The Poetics of Translation. Toronto: University of Toronto Press, 1985.

STEINER, T. R. 1975. English Translation Theory, 1650-1800. Amsterdam: Rodopi, 1975.

STYAN, J. L. 1986. Restoration Comedy in Performance. Cambridge: Cambridge University Press, 1986.

THACKER, Jonathan. 2008. History of performance in English. In C. Boyle, and D. Johnston (eds.). The Spanish Golden Age in English. Perspectives on Performance. London: Oberon Books, 2007: 15-30.

VENUTI, Lawrence. 2004. The Translator's Invisibility: A History of Translation. London/New York: Routledge, 1995.

WILSON, John Harold. 1965. A Preface to Restoration Drama. Boston: Houghton Mifflin Company, 1965.

ZATLIN, Phyllis. 2005. Theatrical Translation and Film Adaptation. Clevedon: Multilingual Matters, 2005.

ZUBER-SKERRITT, Ortrun (ed.). 1984. Page to Stage. Theatre as Translation. Amsterdam: Rodopi, 1984. 


\section{Dr Jorge Braga Riera}

Department of English Studies,

Faculty of Philology, Complutense University of Madrid / ITEM / ILMYT,

Plaza Menéndez Pelayo s/n, 28040 Madrid, Spain

jbragariera@filol.ucm.es

Jorge Braga Riera is Associate Professor in the Department of English Studies at the Complutense University of Madrid, where he teaches graduate and undergraduate courses. Additionally, he has worked as a professional translator for major Spanish publishing houses. His research lines are mainly focused on literary translation (principally drama) and contrastive studies (Spanish-English, English-Spanish), on which he has written book chapters and articles in national and foreign journals. Within this line he has published the following volumes: La traducción al inglés de las comedias del Siglo de Oro (Madrid, Fundamentos, 2009), Classical Spanish Drama in Restoration English (1660-1700) (Amsterdam/Philadelphia, John Benjamins, 2009) and Herramientas y técnicas para la traducción inglés-español: los textos literarios (Madrid, Escolar y Mayo Editores, 2015, together with Dr. J.P. Rica). He has also edited and co-edited several monographs and dictionaries from a comparative approach (i. e. Diccionario de la recepción teatral en España, Madrid, Antígona, 2020), and he is the general editor of the journal Estudios de Traducción. He is a member of the Madrid Research Theatre Institute and the Institute of Modern Languages and Translation. 